\title{
English As a Foreign Language Learners' and Their Teacher's Feedback on Form Focused Instruction
}

\author{
Yunus Emre Akbana ${ }^{1}$, Aysun Yavuz ${ }^{2}$ \\ ${ }^{1}$ Department of Foreign Language Education, Faculty of Education, Kahramanmaraş Sütçü Imam University, \\ Kahramanmaraş, Turkey \\ ${ }^{2}$ Department of Foreign Language Education, Faculty of Education, Çanakkale Onsekiz Mart University, Çanakkale, Turkey
}

Corresponding Author: Yunus Emre Akbana, y.emreakbana@hotmail.com

Article Type: Research Article

Acknowledgement: The preliminary findings of this study have been shared via an oral presentation at the "10th International ELT Research Conference" between 25-27 April 2018. This study further reports on the partial results of a PhD dissertation conducted by the first writer, under the supervision of the second author at Çanakkale Onsekiz Mart University.

To Cite This Article: Akbana Y. E., \& Yavuz, A. (2021). English as a foreign language learners' and their teacher's feedback on form focused instruction. Eğitimde Kuram ve Uygulama, 17(1), 84-97. doi: 10.17244/eku.935475

Ethical Note: Research and publication ethics were followed. In this study, the data were collected before 2020, and voluntary participation of study group was observed during the data collection period.

\section{Yabancı Dil Olarak İngilizce Öğrenenlerin ve Öğretmenlerinin Yapı Odaklı Öğretime Dair Görüşleri}

$$
\text { Yunus Emre Akbana }{ }^{1}, \text { Aysun Yavuz }^{2}
$$

${ }^{1}$ Yabancı Diller Eğitimi Bölümü, Eğitim Fakültesi, Kahramanmaraş Sütçü İmam Üniversitesi, Kahramanmaraş, Türkiye ${ }^{2}$ Yabancı Diller Eğitimi Bölümü, Eğitim Fakültesi, Çanakkale Onsekiz Mart Üniversitesi, Çanakkale, Türkiye

Sorumlu Yazar: Yunus Emre Akbana, y.emreakbana@hotmail.com

Makale Türü: Araştırma Makalesi

Bilgilendirme: Bu çalışmanın ön sonuçları 25-27 Nisan 2018'de düzenlenen "10th International ELT Research Conference" isimli etkinlikte bildiri olarak sunulmuştur. Bu makale ise, birinci yazarın ikinci yazarın danışmanlığında Çanakkale Onsekiz Mart Üniversitesi'nde tamamladığı doktora tezine dayalı olarak oluşturulmuştur.

Kaynak Gösterimi: Akbana Y. E., \& Yavuz, A. (2021). English as a foreign language learners' and their teacher's feedback on form focused instruction. Eğitimde Kuram ve Uygulama, 17(1), 84-97. doi: 10.17244/eku.935475

Etik not: Araştırma ve yayın etiğine uyulmuştur. Bu çalışmada veriler 2020 yılı öncesi toplanmış olup, veri toplama sürecinde katılımcıların gönüllü katılımı gözetilmiştir. 


\title{
English As a Foreign Language Learners' and Their Teacher's Feedback on Form Focused
}

\section{Instruction}

\author{
Yunus Emre Akbana' ${ }^{1}$ Aysun Yavuz ${ }^{2}$

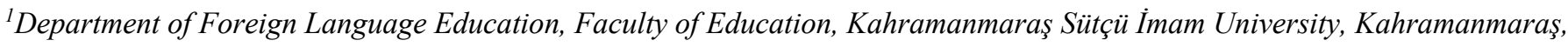 \\ Türkiye \\ ${ }^{2}$ Department of Foreign Language Education, Faculty of Education, Çanakkale Onsekiz Mart University, Çanakkale, Türkiye
}

ORCID: https://orcid.org/0000-0002-5707-3564

ORCID: https://orcid.org/0000-0001-6838-8695

\begin{tabular}{|c|c|}
\hline Abstract & Article Info \\
\hline $\begin{array}{l}\text { The study employs a qualitative research methodology incorporating Form Focused } \\
\text { Instructional Design (FFID) with } 20 \text { young adult university students of English and an EFL } \\
\text { university teacher. The FFID was aided with the Ellis' }(1998,2016) \text { instructional stages of } \\
\text { input, intake, output, feedback, and the stages were backed up with uptake as an addition. } \\
\text { The study targets dwelling on the participants' views towards FFID via learner and teacher } \\
\text { journals and semi-structured interviews. Through an inductive content analysis, the } \\
\text { triangulated findings indicated the benefits of FFID available both to the learners and the } \\
\text { teacher. To list a few, FFID afforded opportunities for learners to make discoveries, engage } \\
\text { with learning the language, promote learning and show other developments in affective, } \\
\text { cognitive and professional dimensions. FFID also assisted the teacher to be motivated and } \\
\text { get engaged within the process more actively. On the other hand, FFID raised limited } \\
\text { negative issues such as the inhibitors to engage in tasks and lack of motivation and attention } \\
\text { due to affective factors and conditions. However, these factors and conditions are identified } \\
\text { as significantly important for the teacher to consider students' achievement and } \\
\text { development. Accordingly, the study concludes with several methodological and } \\
\text { pedagogical implications to run FFID in EFL settings. }\end{array}$ & $\begin{array}{l}\text { Keywords: English language } \\
\text { teaching, Focus on form, Form } \\
\text { focused instruction, Learner } \\
\text { journal, Teacher journal, } \\
\text { Uptake. }\end{array}$ \\
\hline
\end{tabular}

Etik not: Araştırma ve yayın etiğine uyulmuştur. Bu çalışmada veriler 2020 yılı öncesi toplanmış olup, veri toplama sürecinde katılımcıların gönüllü katılımı gözetilmiştir.

Ethical Note: Research and publication ethics were followed. In this study, the data were collected before 2020, and voluntary participation of study group was observed during the data collection period. 


\section{Yabancı Dil Olarak İngilizce Öğrenenlerin ve Öğretmenlerinin Yapı Odaklı Öğretime Dair Görüşleri}

$\ddot{\mathbf{O z}}$

Çalışma, İngilizceyi yabancı dil olarak öğrenen 20 genç yetişkin üniversite öğrencisi ve öğretmenlerinin Yapı Odaklı Öğretim Tasarımı (YOÖT) ile ilgili görüşlerini içeren nitel bir araştırma desenine sahiptir. YOÖT, Ellis'in $(1998,2016)$ girdi, algılamalı girdi, çıktı ve geri bildirim öğretim aşamaları ile oluşturulmuștur ve bu aşamalara ek olarak edimsel çıkarım aşaması ile desteklenmiştir. Çalışma, katılımcıların öğrenci ve öğretmen günlükleri ve yarı yapılandırılmış görüşmeler yoluyla YOÖT'a yönelik görüşlerine odaklanmayı amaçlamaktadır. Tümevarımsal bir içerik analizi ile veri üçlemesi yapılmış bulgular, YOÖT'ın hem öğrenciler hem de öğretmen için faydalarını ortaya koymuştur. Bu faydalardan birkaçını listelemek gerekirse, YOÖT öğrencilere keşifler yapma, dil öğrenmek için çaba gösterme, öğrenmeyi teşvik etme ve duygusal, bilişsel ve mesleki boyutlarda diğer gelişmeleri gösterme fırsatlarını sağlamıştır. Ayrıca, YOÖT öğretmenin motive olmasına ve sürece daha aktif bir şekilde dahil olmasına yardımcı olmuştur. Öte yandan, uygulanan YOÖT ile aktivitelere dahil olmaya yönelik engeller, duygusal faktörler ve koşullar nedeniyle motivasyon ve dikkat eksikliği gibi bazı sınırlı sayıdaki olumsuz konuları gündeme getirmiştir. Bununla birlikte, öğretmenin öğrencilerin başarılarını ve gelişimlerini dikkate alması açısından bu faktörler ve koşulların ciddi derecede önemli olduğu vurgulanmıştır. Buna göre, çalışma İngilizcenin yabancı dil olarak öğretildiği ortamlarda YOÖT’1 kullanmak için çeşitli yöntemsel ve pedagojik öneriler ile sonuçlanmaktadır.
Makale Bilgisi

Anahtar kelimeler: Edimsel çıkarım, İngiliz dili öğretimi, Öğrenici günlüğü, Öğretmen günlügü, Yapı odaklı öğretim, Yapıya odaklanma.

Makale Geçmişi:

Geliş: 10 Mayıs 2021

Düzeltme: 01 Haziran 2021

Kabul: 11 Haziran 2021

Makale Türü: Araștırma

Makalesi 


\section{Introduction}

The quest for embarking new techniques or approaches to language teaching has been always in the spotlight. To achieve this aim, many confronting variables such as age, aptitude, learner preferences, the concept of motivation, cognitive and affective factors aligned with the several programme requisites such as the choice of materials, activities, syllabus type, curriculum objectives and outcomes have garnered the attention of researchers for so long. This purpose has been served in many studies with quantitative and/or qualitative research methods favouring Form Focused Instructional Design (FFID) as an instructional option to language teaching (Coşgun Ögeyik, 2018; Doughty \& Varela, 1998; Ellis, 2016; Fuente, 2006; Littlewood, 2007; Loewen, 2005; 2018; Mennim, 2007; Tedick \& Young, 2018). However, Ellis (2001) suggests conducting more empirical studies particularly with qualitative research methods. For this reason, the present study focuses on the merits of qualitative research methods drawn on a FFID aiding Ellis's $(1998,2016)$ instructional stages - input, intake and output — with an additional focus on uptake reflected by students. The present study also addresses beginner level learners by following Ellis' (2020) recommendation to run FFID with learners of such proficiency level.

\section{Theoretical Background}

In the field of Second Language Acquisition (SLA), several input and output theories; namely, Input Theory/Comprehensible Input Hypothesis (Krashen, 1985), Output Theory/The Comprehensible Output Hypothesis/The Output Hypothesis (Swain, 1985), Noticing Hypothesis (Schmidt, 1990) and Interaction Hypothesis (Long, 1996), have been researched in language pedagogy over the last four decades. Employing these hypotheses/theories under a language teaching approach has become an option. The earlier studies of Communicative Language Teaching (CLT) were found to be ineffective according to Millard (2000) since these studies typically represented the focus on the formal instruction heavily. In time, research shows evidence that formal instruction, particularly Form Focused Instruction (FFI) can play a major role in adhering a harmony of Ellis' (1998) instructional intervention stages (input, processing, output and feedback) within the scope of CLT (El-Dakhs, 2015). Accordingly, El-Dakhs (2014) evaluates FFI as an approach that 'emphasizes relating forms to their communicative functions, noticing forms during communicative interaction and retrieving forms in communicative contexts' (p. 6). In addition, Ellis (1990) proposes FFI as a solution for learners to get engaged in the language features and as an approach for teachers to implement. Following Schmidt's (1990) Noticing Hypothesis, Ellis (2001) proposed Focus on Form (FoF) as a learning/teaching approach/technique by means of 'any planned or incidental instructional activity that is intended to induce language learners to pay attention to linguistic forms' (p. 1-2).

Counterbalancing FoF in CLT with noticing in classroom environment, there raises the need for investigating teaching and learning process of grammar. Approaches to language teaching with an emphasis on grammar are examined with the above theories, hypotheses, and techniques; however, each context has its own merits or cons. For example, in Iranian EFL context, Shabani and Hosseinzadeh (2019) conducted a quasi-experimental study with pre-emptive and reactive FoF techniques. They concluded that students developed their L2 writing accuracy in both techniques, which offered the form in learners' attention. In a recent study, Rahimi, Ahmadian, Amerian and Dowlatabadi (2020) compared the durability of input flooding, which is a common technique in FoF studies, with jigsaw tasks. Rahimi et al. (2020) found that although input flooding can be preferable to have immediate impact on students' linguistic development, jigsaw tasks could have longer lasting effect. It was also found in Boostan Saadi and Saeidi's study (2018) that students receiving input-based FFID outperformed the ones who received output-based FFID, meaning input could serve with the perceptual saliency.

Since the aim in FoF is to afford students to be able to make discoveries through getting engaged in the language learning process actively (Coşgun Ögeyik, 2018), corrective feedback plays a major role to enable the students to uptake their intake (Sheen, 2004). Previous studies revealed the possible link between corrective feedback and the uptake in different areas of language; for example, pronunciation (Sheen, 2004), lexical stress (Hassanzadeh \& Salehizadeh, 2020), and identifying lexical categories in a virtual environment (Akiyama, 2019). Evaluating this particular link, revision through corrective feedback contributes to students' writing considerably. In a recent study, Ekanayaka and Ellis (2020) evaluated three groups of students' writing development. The students were exposed to corrective feedback and grouped into three: no-, partial- and full-revision. Finally, Ekanayaka and Ellis (2020) concluded that revision subsequent to corrective feedback could improve grammatical accuracy in producing writing. In Turkish context, Koçak (2020) provided a remedial teaching of relative clauses under the philosophy of FFI and found that explicit teaching contributed to young adult learners' grammatical accuracy significantly. 


\section{Statement of the Problem}

As Kırkgöz (2007) argues that the use of explicit grammar teaching in Turkey is highly employed, it was also seen in setting of this study because EFL college teachers had a tendency to teach English via teaching grammar rules rather than getting the students involved in the process of discovery of rules through meaningful activities. Therefore, a FFID approach based on rule discovery and noticing techniques was employed, and accordingly this study attempts to reveal the following two purposes: (1) understanding how the students view FFID for their own learning and (2) finding out how the teacher views FFID for his professional development. In order to achieve these two purposes, the following research question was posed:

What are the students' and the researcher teacher's perceptions of form focused instruction?

Employing this research question, the present study is devoted to contributing to the SLA research in the Turkish university context by differing from previous studies in investigating young adult learners' and their EFL teacher's qualitative views over FFID.

\section{Method}

The present study employs a descriptive research approach in which there is a specific variable (i.e. FFID) to be described (Karasar, 2008). The researchers attempted to describe the effect of FFID treatment on the L2 English development of 20 young-adults at a state university in Turkey. To do so, the first author of this study acted as a researcher teacher. His and students' views were investigated through a qualitative research design by employing semistructured interviews, and learner and teacher journals.

\section{Treatment and Data Collection}

Once the participants were informed about the purpose of the study and their consent was granted, the researcher teacher followed the principles of FFID treatment over a time period of 12 weeks. The FFID informed materials were delivered in six weeks and the remaining six weeks were devoted to semi-structured interviews subsequent to each treatment week. In other words, in one week the materials were delivered for providing the input, in the following week the input was examined and interviews were administered accordingly. The treatment covered six different grammar topics selected within the light of a pilot study and crosschecked with the results of a proficiency test prior to the launch of the study. The treatment involved (1) prepositions of time, (2) adjectives ending with -ed/-ing, (3) comparatives and superlatives, (4) stative verbs, (5) basic gerunds and infinitives, and (6) compounds of some, any and no. Students' language proficiency level was identified as A2 according to a further institutional placement test.

The treatment was informed by Ellis' (1998) instructional design that focused on input, intake, output and feedback stages. The input stage utilized enhanced input, comprehensible input $(+1)$, and input flooding techniques. The second stage; intake, was more salient with noticing technique. Regarding the output stage, the comprehensible output hypothesis was promoted through writing skill. As to the final stage, feedback was implemented on students' written productions by following an interactive corrective feedback cycle where the learners passed through three sub-stages: (1) self-edit, (2) peer-edit, and (3) teacher-edit. In addition, a fifth stage referring to uptake was also embedded into the FFID by allowing the learners to keep self-reflective uptake sheets during each treatment in order to assist them to keep learner journals.

Gaining the learner journals by following the process given above, eight volunteer students were interviewed on the effectiveness of FFID. Both the learners' and the researcher teacher's journals were also checked during the interviews and initial common ideas were verified. This consecutive data collection process identified the qualitative data out of a total of 48 semi-structured interview transcriptions, 120 learner reflections provided by the participant students and 6 reflections by the teacher.

\section{Data Analysis}

The data were exposed to inductive or in other words conceptual content analysis by following the procedures of Saldaña (2021) in coding the data. An example is provided below: 


\begin{tabular}{|l|l|l|}
\hline $\begin{array}{l}\text { Bugünkü gibi değişik } \\
\text { materyallerle } \\
\text { geldiğinizde } \\
\text { derslerimize resmen bir } \\
\text { yeni bir soluk } \\
\text { getiriyorsunuz ve } \\
\begin{array}{l}\text { sk1lmadan } \\
\text { öğreniyorum. }\end{array}\end{array} \mid \begin{array}{l}\text { More interest with } \\
\text { class with different } \\
\text { materials like today, } \\
\text { you actually bring a } \\
\text { breath of fresh air and I } \\
\text { can lear without } \\
\text { getting bored. }\end{array}$ \\
\hline $\begin{array}{l}\text { Original quote from } \\
\text { Learner Journal in } \\
\text { Turkish }\end{array}$
\end{tabular}

Figure 1. A sample from learner journal data on identifying concepts. Adapted from Cabaroğlu and Rathert (2017, p. 166).

Figure 1 illustrates three stages of the content analysis method. Initially, the data were retrieved from the learner journals, which were written in Turkish, the native language of the learners. Secondly, the texts were translated into English and were sent to independent raters in order to establish the initial coding stage. Subsequently, the initial codes were established individually and the raters were asked to come to an agreement on building categories and themes. The categories and themes were identified by several concepts from the literature such as affective filter, autonomy and cognitive dimensions. Following is a sample on subsequent coding.

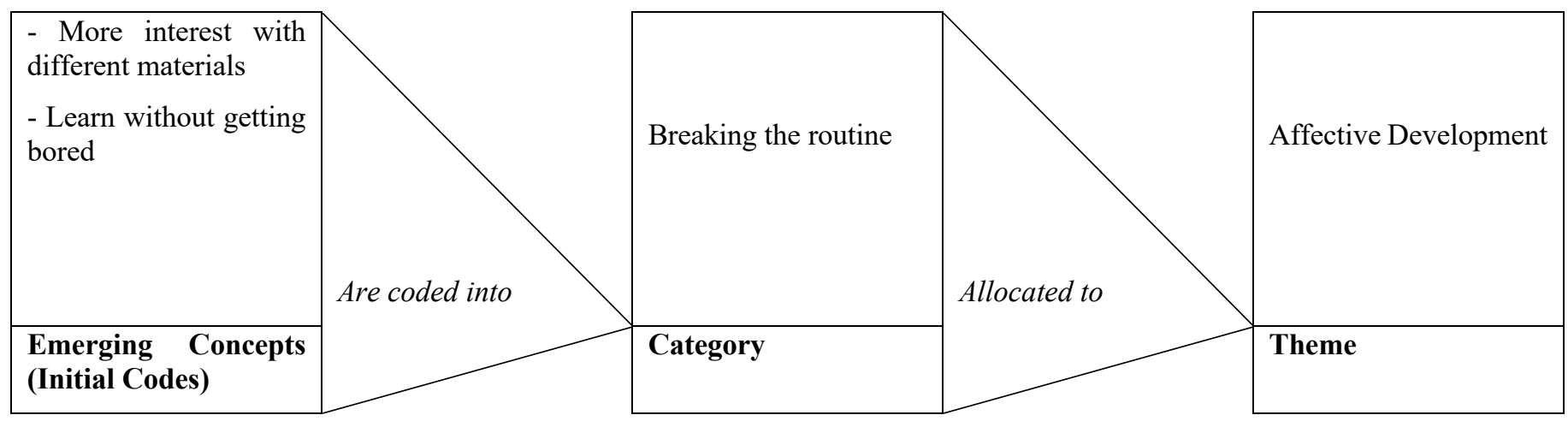

Figure 2. From coding to theme (Tracking Figure 1). Adapted from Cabaroğlu and Rathert (2017, p. 167).

As illustrated in Figure 2, by following a process from initial coding different categories were clustered and the relevant themes were identified. Upon the agreement of the final coding of the data between the independent raters, the reliability score obtained was $92 \%$.

\section{Findings}

This section provides the data findings obtained from three sets; semi-structured interviews, learner and teacher journals separately. Table 1 below illustrates the results from learner journals.

Table 1 lists seven themes emerging out of students' views about the FFID implementation. Most of the elicited views were clustered into 'Affective Development' with a total number of 118 statements while the least frequent number of statements (21) constituted 'Willingness to Communicate'. 'Affective Development' was comprised of categories mostly favouring the treatment useful.

Usefulness - P3: "I think this sort of teaching style is very beneficial for my learning."

Enjoyable - P7: "I really love discovering rules like a game with my friends." 
Confidence Booster -P9: "These materials helped me to discover my potentials, now I can handle learning better."

Breaking the Routine - P16: "Studying English everyday with the same coursebook has become boring but I learn English better when you bring your worksheets."

Challenge - P17: "It is usually difficult to understand grammar because you don't explain it on the board but out of the materials. However, the result is always fine."

Responsibility - P19: "Collaborating with others and having a feeling of studying at home makes me more conscious."

Table 1. Students' views elicited from learner journals.

\begin{tabular}{ll}
\hline Theme & Category \\
\hline Affective Development (118) & Usefulness (44) \\
& Enjoyment (37) \\
& Confidence Booster (16) \\
& Breaking the Routine (8) \\
& Challenge (7) \\
& Responsibility (6) \\
Cognitive Development (70) & Autonomy (22) \\
& Satisfaction (19) \\
& Growing Interest (16) \\
& Developing Study Habits (13) \\
Inhibition to Learning (57) & Personal Problems (17) \\
& Concentration Spam (16) \\
& Failure (14) \\
Cognitive Maturity (43) & Boring (10) \\
& Noticing (18) \\
Willingness to Learn (42) & Learning from Mistakes (14) \\
Uptake (30) & Retention (11) \\
& Feeling of Valued (28) \\
Willingness to Communicate (21) & Feeling of Progress (14) \\
\end{tabular}

These categories shed light on a set of merits of FFID. For example, students found FFID useful and enjoyable because P3 clearly used the word beneficial and P7 used the phrase like a game. As mentioned by P9, students also developed confidence in learning through FFID based materials. It is also evident that the routine way of using a coursebook resulted in monotony previously but the FFID seemed to break such a routine as P16 mentioned. FFID also enabled students to get engaged in learning because P17 signalled on the virtue of achieving challenging tasks to discover grammar. Similarly, FFID helped students develop learning autonomy as voiced by P19. The second highest responses (70) from the students formed the theme 'Cognitive Development'.

Autonomy - P1: "I can transfer the noticing technique to my other self-studies."

Satisfaction - P4: "I believe that using these materials in class helps me not to study grammar and vocabulary further."

Growing Interest - P11: "The more I find myself into the activities, the better improvement I see in my world knowledge because reading passages provide a lot of interesting information."

Developing Study Habits - P18: "I started to make use of all the phrases and rules I got engaged in these lessons. So, I can study better without memorization."

FFID seemed to contribute to students' cognitive development in learning English by equipping the students with enhancing and flooding the input through input typography techniques. In this regard, P1 stressed on the noticing technique, which helped them develop autonomy. It may be interesting for students to use the particular terminology noticing; however, running semi-structured interviews led to discussions and negotiations between the teacher and the students. Therefore, students became familiar with such terms cognitively. Another contribution of FFID is students' 
satisfaction, which is a difficult issue to achieve in teaching. However, as P4 indicated, there was a feeling of satisfaction with the sufficiency and learnability of the materials used in the treatment. It is usually difficult to serve materials to students' interests due to a myriad of factors but students already voiced the joy and benefits of such interventions. Additionally, the input featured students' attention because P11 both realised their effort to learn and found the reading passages informative. Another similar and dominant feature of FFID was found getting students engaged in their own learning. P18 noted discovering the language rules rather than memorizing the isolated rules. On the other hand, one theme emerged with a negative meaning; 'Inhibition to Learning' with 57 statements.

Personal Problems - P15: "I'm sorry because I'm sleepy in the class hours and cannot focus enough because I have financial problems so I have to work at a part-time job."

Concentration Spam - P4: "The activities are fine but I cannot catch the pace of the class because it requires being active all the time."

Failure -P5: "I study a lot but my exam results always disappoint me and I don't want to study anymore."

Boring - P1: "Figuring out the rules is a boring job for me, why don't you just give us the rules in a list."

Although other themes represent the impact of FFID in a positive way, the theme 'Inhibition to Learning' employs categories that are interrelated to each other in a way that hinders students' learning. Among these categories, students' 'Personal Problems' need further consideration. For example, P15 expressed their financial problems which in turn affected their time management in their school and home studies. Another issue raised consideration for individual differences. Thus, instructor's teaching pace and students' catching the pace should be tuned because P4 could not concentrate sufficiently. Apart from these issues, fear of 'Failure' was also seen to deteriorate students' learning. Specifically, P5 related their low marks causing reluctance to learn. In addition, though students' encouragement for engaging with the tasks was seen as a facilitator for their learning, it did not account the same for all students. Some students found it boring and signalled their need for focus on forms. For instance, P1 noted on their need to learn grammar via an explicit teaching model and found the treatment boring since it would cost more effort for them. Another theme was coded as 'Cognitive Maturity'.

Noticing - P14: "I can learn two very similar or complex issues by circling one and underlining another."

Learning from Mistakes - P5: "When we studied with our peers on our writing tasks, I had the opportunity to learn from others' mistakes though I did not see the same ones on mine."

Retention - P20: "We do not only learn something immediately but we use it many times firstly ourselves, then with class mates, later with the teacher and with others on our social network. So, I am sure, I cannot forget what I learn in these lessons."

Although the noticing technique was exemplified in the previous theme with earlier findings on students' awareness, which in turn contributed to their cognitive development, here it is labelled with direct and specific reference to students' 'Cognitive Maturity'. For example, FFID led the students to gain individual learning pathways. Particularly, P14 emphasized their effective use of noticing technique through typographic enhancement techniques. Also, FFID helped them study collaboratively and take responsibility. P5 noted that they could not find their own mistakes over their own written productions, but when it came to take responsibility and evaluate a classmate's written performance, P5 realized what sort of mistakes they had made. They had the opportunity not only to judge others' performances but also to get involved in the learning process collaboratively. Additionally, as P20 recorded, FFID had long-lasting effect in their learning through practicing. The fourth theme was identified as 'Willingness to Learn'.

Feeling of Valued - P8: "I want to thank you for putting so much effort by preparing such perfect documents and engaging us with these activities."

Feeling of Progress - P12: "I have to confess that whenever we follow the coursebook, I feel improved, it is OK, but whenever we follow your materials like a team in the class, I feel more improved."

The students valued FFID and this may be due to the common idea in education that students mirror teachers' efforts. For example, P8 expressed their gratitude towards the teachers' preparedness, for this reason, the student felt being valued and improved with their own word perfect. Students also compared FFID treatment with that of the traditional lecturing method where other teachers' coursebook dependency was dominant. This led to the emergence of 
the category 'Feeling of Progress'. P12 found both methods endeavouring for their learning; however, they rewarded FFID making more contribution to their language development. Another theme was identified as 'Uptake' with two categories.

Comprehension - P6: "At the beginning, I was quite unsure about how to distinguish some complex grammar rules like for gerunds and infinitives, but now, I understand them over time by discovering."

Consciousness - P19: "I know my own learning methods that my favourite ones are discovering rules, new words, phrases, and making use of them in both writing and speaking."

The impact of the treatment was also evidenced with students' improved comprehension and consciousness towards language learning, which in turn classified into the theme 'Uptake'. To illustrate, P6 reflected on their own comprehension way of understanding a grammar topic and touched upon the unnecessity of memorizing grammar rules rather than discovering. This could be an impact of the treatment on assisting the students to comprehend grammar more effectively. Similarly, P19 sounded as a conscious language learner by learning the target linguistic features and transferring them into productive skills. The last positive theme was 'Willingness to Communicate' with one labelled category.

Collaboration - P5: "Today, I realized that I'm not the one who learns by himself, but the one who wants to work with others on digging in the materials and talking about what is learnt with the teacher."

Although the participants more or less in the previous categories stressed collaboration, the emergent category here represents students' willingness to communicate. The reason is due to the nature of collaboration, which invokes more interest among students to communicate with each other. Therefore, FFID may seem to indicate a tendency towards communication relying on intrinsic willingness. For example, P5 defined their own learning style and stressed their willingness to communicate with other classmates and building a sense of collaboration, which would result in more effective learning progress for them.

To sum up, the findings from learner journals revealed that students favoured this pedagogic option. One possible outline of this kind could be represented with the students' interlanguage development as evidenced by the findings of their affective development that the students found the treatment useful, enjoyable, breaking the routine way of learning, developing confidence and responsibility and challenging but fruitful. This outline also included students' cognitive development through building sense of autonomy, satisfaction, growing interest to the learning process and developing study habits that they can transfer into their self-study agenda. Other positive findings succinctly revealed that this sort of instruction contributed to students' cognitive maturity, skill of uptake, and willingness to learn and communicate. Apart from these positive issues, students' personal problems, failure from exams and seeing the treatment boring time to time were found to hinder students from learning. Regarding the students' views elicited from the semi-structured interviews, the content analysis revealed students' learning experiences and the impact of the intervention.

\section{Students' Learning Experiences Before and Within the Treatment}

Most of the students defined their previous EFL teachers from secondary to high-school as rule supplier, grammar book and teachers of English like Mathematics or Turkish and those who used L1 (Turkish) in their teaching. In brief, they disfavoured their previous teachers' traditional grammar teaching approach. On the other hand, a great majority of students found the FFID treatment facilitating the learning process.

P5: “At high-school, I used to study by using my classmates' notebooks, but it is nonsense because I learnt how to use my notebook better and mine is the best for me."

P6: "In the past, we had to follow a list of vocabulary provided by the teacher, but here, I make my own lists."

P8: "I can understand what is said in a text, which was the only thing I learnt until coming university. But now, I can say and write what I want to say in addition to what I see and hear."

Students voiced on their perceived comparison of the teaching methods they were exposed to before and within the study with statements showing similarity to the views elicited in the learner journals. P6 recorded on developing study habits by taking notes, which was also a concern of P18 from the learner journals under the theme of cognitive development. In addition, P5 mentioned developing 'Autonomy' that was also under the theme of 'Cognitive 
Development' in the learner journals. P8 signalled the attainment they had gained by the reading skill prior to university; however, they indicated becoming a more competent user of language with the use of other skills; listening, speaking and writing. As seen from the excerpts outlined above, it is apparent that students commonly experienced teacher centred approach before university, yet they opted for such inclusion of FFID in their learning syllabus by showing indications of learner centred approach and developing study habits.

\section{Impact of Activities}

The interviewed students evaluated the activities in terms of their learning endeavours. The category 'Impact of Activities' emerged with positive issues. Several sample extracts are shown below.

P2: "We were aware of what we were doing in classes because the activities led us to clear aims."

P3: "The activities helped me find out my own way of learning through modelling from reading and producing into writing."

P4: "The activities were designed to express our opinions by writing, which is the skill I always wanted to develop."

P5: "The activities were sometimes too demanding but easy to use."

P7: "Now, I can underline, circle, make bold, uppercase and italicise the most important things in my mind while I'm reading a passage".

The elicited views match with that the views gathered through learner journals. For example, P2 signalled developing consciousness, P3 addressed developing study habits, P4 touched upon the feeling of satisfaction, P5 stressed on the challenging side of the activities but leading to success, and finally, P7 referred noticing technique assisting them to develop cognitive maturity and autonomy towards learning. To sum up, the students perceived such activities beneficial for their own learning endeavours. Therefore, the findings gathered from the semi-structured interviews share a great majority of common ideas reported in their learner journals. Drawing attention from this match, Table 2 is dedicated to dwelling on the researcher teacher's views below.

Table 2. Teacher's views

\begin{tabular}{ll}
\hline Positive Issues & Negative Issues \\
\hline Communicated & Students' Mood \\
Enjoyed & Teaching \\
Motivated & Timing \\
Satisfied & \\
Eager & \\
\hline
\end{tabular}

Table 2 indicates two themes around which mostly positive issues were encoded from the teacher's journals. On the other hand, several classroom management problems were also identified.

Communicated: "Today, I felt successful in developing a good rapport with my students thanks to the design of the activities which put all of us in a team work."

Enjoyed: "I think, the best part of running FFID is that it put a smile on my face when I left the classroom."

Motivated: "Seeing the students digging into the materials encourages me more than anything."

Satisfied: "What makes a good job in teaching is seeing student achievement. Today, I observed students using the language forms taught four weeks ago."

Eager: "I ran to the classroom with excitement and joy carrying the whole sheets to work on with my students. This must be to do with the enthusiasm that I saw in the eyes of my students."

As it is apparent from the extracts above, the teacher perceived FFID serving a lot of benefits for his own professional development. Also, the teacher's views underline a large match of ideas with those of the students'. Table 3 compares the matching positive statements below. 
Table 3. Teacher's and students' common positive statements

\begin{tabular}{|c|c|c|c|c|}
\hline $\begin{array}{l}\text { Theme from } \text { Teacher } \\
\text { Journals }\end{array}$ & $\begin{array}{l}\text { Related Categories from } \\
\text { Teacher Journals }\end{array}$ & $\begin{array}{l}\text { Themes from Learner } \\
\text { Journals }\end{array}$ & $\begin{array}{lr}\text { Related } & \text { Categories } \\
\text { from Learner Journals }\end{array}$ & $\begin{array}{l}\text { Categories from } \\
\text { Semi-Structured } \\
\text { Interviews } \\
\end{array}$ \\
\hline \multirow{6}{*}{ Positive Issues } & Communicated & Willingness to & Collaboration & \multirow{6}{*}{$\begin{array}{l}\text { Impact and Learning } \\
\text { Experiences }\end{array}$} \\
\hline & & Communicate & & \\
\hline & Enjoyed & Affective Development & Enjoyment & \\
\hline & Motivated & Willingness to Learn & $\begin{array}{l}\text { Feeling of Being } \\
\text { Valued }\end{array}$ & \\
\hline & Satisfied & Cognitive Development & Satisfaction & \\
\hline & Eager & & Collaboration & \\
\hline
\end{tabular}

Table 3 illustrates that the following couple of matches were found between teacher's and students' emergent categories: 'Communicated' (T) and 'Collaboration' (S), 'Enjoyed' (T) and 'Enjoyment' (S), 'Motivated' (T) and 'Feeling of Valued' (S), and 'Satisfied' (T) and 'Satisfaction' (S). These matches also overlapped with the two broad categories retrieved from the semi-structured interviews. Both parties' views emphasize mutual interaction in terms of (I) 'Affective Development' with enjoying learning and teaching; (II) 'Willingness to Learn' and 'Willingness to Communicate' with 'Feeling of Valued' by the students and (III) 'Collaboration'; and 'Cognitive Development' with the satisfaction that the teaching and learning outcomes afforded. Apart from these positive issues, the teacher reflected on his experience with several issues in a negative way.

Students' Mood: "It is getting a hard job to catch the interest of three particular students in my classroom. They seem to be passive, silent and not interested in class activities." (after the first session)

Teaching: "Most of the time they ask for the rules to be written on the board." (after the third session)

Timing: "Last week, I had difficulties in managing the class because the students could not understand what to do and today it cost me to experience timing problem." (after the second session)

The above samples address the common problems that the teacher experienced at the beginning of the study; however, there is none evidenced in the developmental stages of the treatment. In the first session, the teacher had a sense that getting the students involved in the treatment would be a very challenging job and this resulted in a timing problem in the second session. However, the teacher did not report on any problems in the following weeks. All in all, these issues may need to be given consideration for professional development. Students also addressed the teacher's negative issues partly in the earlier section. Accordingly, Table 4 compares the matching statements below.

Table 4. Teacher's and students' negative overlapping statements

\begin{tabular}{|c|c|c|c|}
\hline $\begin{array}{l}\text { Negative Issues from } \\
\text { Teacher Journals }\end{array}$ & $\begin{array}{l}\text { Overlapping Themes from } \\
\text { Learner Journals }\end{array}$ & $\begin{array}{l}\text { Overlapping Categories from } \\
\text { Learner Journals }\end{array}$ & $\begin{array}{l}\text { Overlapping Categories from } \\
\text { Semi-Structured Interviews }\end{array}$ \\
\hline $\begin{array}{l}\text { Students' Mood } \\
\text { Teaching } \\
\text { Timing }\end{array}$ & Inhibition to Learning & $\begin{array}{l}\text { Personal Problems } \\
\text { Finding the Course Boring }\end{array}$ & Learning Experiences \\
\hline
\end{tabular}

Table 4 shows that the teacher's concern as the 'Students' Mood' could be related to the category of 'Personal Problems' because the teacher draws the attention on the passive students. This observation was already reported by P8 that they had a part-time job and could not be active in class. Teacher's 'Teaching' concern could also stem from students' previous learning experiences, which was reported in the semi-structured interviews. This could also be related to finding the course 'Boring' from the learner journals as particular students earlier reported that they did not have any desire to discover the rules but asked for a ready list provided by the teacher. However, this is against to the objective of running focus on form informed instructional design. On the other hand, the teacher was still 'Eager', 'Motivated', and 'Satisfied'. This may mean not a full accomplishment can be guaranteed by using FFID methodology which could be challenging for every teaching and learning contexts. To sum up, both the positive and negative issues elicited from the researcher teacher's journals, students' learner journals and the semi-structured interviews yielded a considerable 
amount of statements favouring the FFID; however, the several negative issues showed overlapping findings which would mean the need for improvement in the treatment.

\section{Discussion}

This study was conducted in an attempt to reveal how both the learners and the researcher teacher conceptualized and perceived form focused instruction through their unique experiences. Both parties indicated mostly positive views in terms of learning and teaching endeavours. Students expressed their linguistic and learning development by building sense of feeling of being valued and progress through learning from mistakes, which created a sense of long-lasting effect of the use of target linguistic features. The overall findings underlined similarity to the potential impact of FFID in promoting the learners' linguistic development as evidenced in the pertinent literature (Doughty \& Varela, 1998; Koçak, 2020; Loewen, 2005; 2018; Tedick \& Young, 2018). Also, both parties reflected on the shift from explicit to implicit knowledge by which FFID is evidenced to improve language learning through the noticing technique in several studies (Ellis, 2016; Fuente, 2006; Loewen, 2018; Mennim, 2007). Similarly, Boostan Saadi and Saeidi (2018) found that students exposed to input-based focus on form outperformed output-based focus on form group and related it to the perceptual saliency in the input. In line with the findings of Doughty and Varela's (1998) study, the learners also indicated positive attitudes towards learning form and meaning simultaneously by building autonomy and developing study habits. Additionally, the teacher showed affective development by defining the treatment as useful and enjoyable. This was noted by Heidari-Shahreza's (2018) study but it only involved learners. In line with the findings of Coşgun Ögeyik (2018), the majority of the findings indicate that learners could develop their skills of making discoveries through engaging with language. In addition, learners and the teacher appreciated the interactive feedback cycle through collaboration and noticing, learning from mistakes and retention. This finding falls into the nature of uptake, which helps learners internalise new forms to use the linguistic knowledge. The particular link between corrective feedback and successful uptake through FFID was also evidenced similarly with the earlier studies (Gholami \& Gholami, 2018).

On the other hand, this study identified several negative issues that would fall into contextual factors and individual differences, which cannot be controlled easily. However, the methodology of this study can shed light on building a more effective environment for teaching and learning. Supporting this, Good and Lavigne (2017) argue heavily on the complex context of classroom and the expectations of teachers. In addition, Littlewood (2007) stresses on the widespread common view that "no single method or set of procedures will fit all teachers and learners in all contexts' (p. 248).

\section{Conclusion}

This study presents 20 students' and their teacher's views on implementing FFID in an EFL setting. The treatment relied on activities informed of input, intake, output and uptake stages meticulously. The underlying philosophy in such design fell into focus on form approach. Therefore, it targeted enabling the students to get engaged in language learning by discovering grammatical forms rather than memorising the isolated rules.

The findings indicate that Turkish young adult students show amelioration in their learning pathways from a comparative perspective of their past learning experiences with of those gained in the FFID period. Also, the findings identified students' affective and cognitive development on forming and integrating learning pathways into their internalised syllabi by building eagerness and preference to this kind of instruction. Besides, this study reveals that opting for FFID in teaching has a lot of motivational aspects for a language teacher. In this respect, implementing FFID in classroom teaching may potentially encourage language teachers. Therefore, there should be language teaching programs with textbooks informed of explicit FFID materials, teaching plans, worksheets so that FFID would become more concrete, visible and articulated among teachers.

The learners' language development and motivational readiness with an emphasis of the teacher's willingness may seem to contribute with a vast number of positive issues to this study. However, the pedagogical and methodological implications need to be well considered in order to increase the impact of FFID by adaptations to the diverse uncontrollable variables in classroom teaching such as different age and language proficiency levels. In this study, the only variable was the learners' language proficiency; however, other variables such as age, gender, aptitude, learning preferences, learner needs at both micro and macro levels should also be embedded into further research so as to sound methodologically more concrete. Although the duration, timing, intensity, techniques, and the syllabus choices were already investigated and developed with a pilot study prior to commencing this study, these factors should well be counterbalanced and further pedagogical options should be well equipped with FFID. Additionally, it is paramount of importance to note that future research on FFID should be sustained on exploring how FFID is best accomplished in a more concrete level for example with ensuring sample videos on a wide range of grammar topics with different learner profiles. 


\section{Contributions of the Researchers}

This study reports on the partial results of a PhD dissertation conducted by the first writer, under the supervision of the second author at Çanakkale Onsekiz Mart University. This manuscript was composed collaboratively from beginning to the end by the authors.

\section{Financial Support and Acknowledgment}

The authors declared that this research received no specific grant from any funding agency in the public, commercial, or not-for-profit sectors.

\section{Conflict of Interest}

The authors have disclosed no conflict of interest. 


\section{Kaynakça / References}

Akiyama, Y. (2019). Using Skype to focus on form in Japanese telecollaboration: Lexical categories as a new task variable. In M. Khosrow-Pour (Ed.) Computer-assisted language learning: Concepts, methodologies, tools, and applications (pp. 617-647). USA: IGI Global.

Boostan Saadi, S., \& Saeidi, M. (2018). The effect of input-based and output-based focus on form instruction on learning grammar by Iranian EFL learners. Journal of English Language Pedagogy and Practice, 11(22), 74-90.

Cabaroğlu, N., \& Rathert, S. (2017). Learner perceptions of an inclusion of bilingual activities to teach English as a foreign language. International Journal of Language Academy, 5(7), 160-180.

Coşgun Ögeyik, M. (2018). The comparative effectiveness of noticing in language learning. International Review of Applied Linguistics in Language Teaching, 56(4), 377-400.

Doughty, C., \& Varela, E. (1998). Communicative focus on form. In C. Doughty \& J. Williams (Eds.), Focus on form in classroom second language acquisition (pp. 114-138). Cambridge: Cambridge University Press.

Ekanayaka, W. I., \& Ellis, R. (2020). Does asking learners to revise add to the effect of written corrective feedback on L2 acquisition?. System, 94, 102341.

El-Dakhs, D. (2014). So, can grammar teaching work? QScience Connect, 6, 1-8.

El-Dakhs, D.A.S. (2015). The integration of form-focused instruction within communicative language teaching: Instructional options. Journal of Language Teaching and Research, 6(5), 1125-1131.

Ellis, R. (1990). Instructed second language acquisition. Oxford: Basil Blackwell.

Ellis, R. (1998). Teaching and research: Options in grammar teaching. TESOL Quarterly, 32(1), 39-60.

Ellis, R. (2001). Introduction: Investigating form-focused instruction. Language Learning, 51 (Supplement 1), 1-46.

Ellis, R. (2016). Focus on form: A critical review. Language Teaching Research, 20(3), 405-428.

Ellis, R. (2020). Task-based language teaching for beginner-level young learners. Language Teaching for Young Learners, 2(1), 427.

Fuente, M. (2006). Classroom L2 vocabulary acquisition: investigating the role of pedagogical tasks and form-focused instruction. Language Teaching Research 10(3), 263-295.

Gholami, L., \& Gholami, J. (2020). Uptake in incidental focus-on-form episodes concerning formulaic language in advanced adult EFL classes. Language Teaching Research, 24(2), 189-219.

Good, T. L., \& Lavigne, A. L. (2017). Looking in classrooms. 11th Ed. Abington: Oxon: Routledge.

Hassanzadeh, M., \& Salehizadeh, M. J. (2020). Focus on form options in second language pronunciation instruction: The case of lexical stress. TESOL Journal, 11(2), e486.

Heidari-Shahreza, M. A. (2018). Focus on form and fun: EFL learners' playful language-related episodes (PLREs). TESL-EJ, 22(2), n2.

Karasar, N. (2008). Bilimsel araştırma yöntemi: Kavramlar, ilkeler, teknikler [Scientific research method: concepts, principles, tecniques]. Ankara: Nobel.

Kırkgöz, Y. (2007). English Language Teaching in Turkey: Policy Changes and their Implementations. RELC Journal, 38(2), 216228.

Koçak, A. (2020). Turkish tertiary level EFL learners' recognition of relative clauses. Journal of Language and Linguistic Studies, $16(4), 1637-1655$.

Krashen, S. D. (1985). The input hypothesis: Issues and implications. New York, NY: Longman.

Littlewood, W. (2007). Communicative and task-based language teaching in East Asian classrooms. Language Teaching, 40(3), 243-249. 
Loewen, S. (2005). Incidental focus on form and second language learning. Studies in Second Language Acquisition, 27(3), 36186.

Loewen, S. (2018). Focus on form versus focus on forms. The TESOL Encyclopedia of English Language Teaching, 5, 1-6.

Long, M. (1996). The role of the linguistic environment in second language acquisition. In Ritchke, W. C. \& Bhatia, T. K. (Eds.), Handbook of language acquisition: Second language acquisition (pp. 413-468). New York, NY: Academic Press.

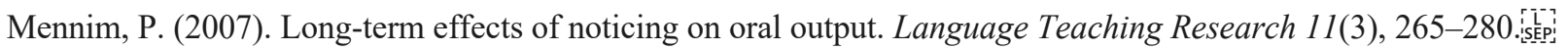

Millard, D. J. (2000). Form-focused instruction in communicative language teaching: Implications for grammar textbooks. TESL Canada Journal, 18(1), 47-57.

Rahimi, S., Ahmadian, M., Amerian, M., \& Dowlatabadi, H. R. (2020). Comparing Accuracy and Durability Effects of Jigsaw Versus Input Flood Tasks on the Recognition of Regular Past Tense/-ed. SAGE Open, 10(2), 2158244020919505.

Saldaña, J. (2021). The coding manual for qualitative researchers (4th Ed.). Los Angelas, CA: Sage.

Schmidt, R. W. (1990). The role of consciousness in second learning. Applied Linguistics, 11(2), 129-158.

Shabani, K., \& Hosseinzadeh, S. (2019). A comparative study of the effects of teacher-initiated planned preemptive and reactive focus on form on L2 learners' accuracy in narrative writing. Innovation in Language Learning and Teaching, 13(1), 76-92.

Sheen, Y. (2004). Corrective feedback and learner uptake in communicative classrooms across instructional settings. Language Teaching Research, 8, 263-300.

Swain, M. (1985). Communicative competence: Some roles of comprehensible input and comprehensible output in its development. In S. Gass, \& C. Madden, (Eds.), Input in second language acquisition (pp. 235-256). Rowley, MA: Newbury House.

Tedick, D. J., \& Young, A. I. (2018). Two-way immersion students' home languages, proficiency levels, and responses to formfocused instruction. International Journal of Bilingual Education and Bilingualism, 21(3), 303-318. 